\title{
Bioethics of the refusal of blood by Jehovah's Witnesses: part 1. Should bioethical deliberation consider dissidents' views?
}

\author{
Osamu Muramoto Kaiser Permanente, Portland, Oregon, USA
}

\begin{abstract}
fehovah's Witnesses' (FWs) refusal of blood transfusions has recently gained support in the medical community because of the growing popularity of "no-blood" treatment. Many physicians, particularly so-called "sympathetic doctors", are establishing a close relationship with this religious organization. On the other hand, it is little known that this blood doctrine is being strongly criticized by reform-minded current and former $\mathfrak{F W s}$ who have expressed conscientious dissent from the organization. Their arguments reveal religious practices that conflict with many physicians' moral standards. They also suggest that a certain segment of "regular" or orthodox $\mathcal{F W S}$ may have different attitudes towards the blood doctrine. The author considers these viewpoints and argues that there are ethical flaws in the blood doctrine, and that the medical community should reconsider its supportive position. The usual physician assumption that $\mathcal{F W s}$ are acting autonomously and uniformly in refusing blood is seriously questioned.
\end{abstract}

(Fournal of Medical Ethics 1998;24:223-230)

Keywords: Religion; Jehovah's Witnesses; blood transfusion; medical ethics; physician-patient relations; informed consent

\section{Introduction}

Jehovah's Witnesses' (hereafter JWs) refusal of medical and surgical treatment using blood products is widely known in the medical community. They are supported by physicians who accept the challenge of "bloodless" treatment, " at least for adult cases. For example, the article, Surgical red blood cell transfusion practice policies, in The American fournal of Surgery ${ }^{2}$ recommends as "policy 1 " to "accept the limitation that allogenic blood cannot be used". This policy recommends involving the local JW hospital liaison committee, appointed by the church organization (Watch Tower Bible and Tract Society, hereafter WTS), for assistance in making decisions. Most medical literature describes JWs' refusal of blood products as definitive, absolute and consistent. Many courts have ruled that a JW's directive not to receive blood products should be complied with even at the cost of the patient's life. On the other hand, medical and judicial decisions rarely take into account how this blood doctrine developed or is enforced in the JW community.

Certain little-known JW practices regarding blood are morally questionable and may require the medical community to re-evaluate its support of the doctrine. The JW religion recently has come under strong criticism by reformers and former members, including a former top official (governing body member) who wrote two books that detail WTS history, religious practices and internal conflicts, ${ }^{34}$ and revealed for the first time the secret inner workings of this religion. The effects of the decisions and policies on the rank and file members of the religion are set out in the writings of other former members. ${ }^{5-7}$ Another important development comes from easy Internet access which has enabled current and former JWs to "come out of the closet" and voice their opinions without fear of retribution. ${ }^{8-10}$ Jehovah's Witnesses have been strongly discouraged from discussing critical religious issues with outsiders, particularly with former members, and can be "disfellowshiped" (excommunicated) for doing so. However, the medical community is generally unaware of these issues.

Thus, the following serious questions arise. Should we physicians continue accommodating the JW patient's request for non-blood treatment based on the "official" position of the WTS alone, disregarding the views of reformers and dissidents, and the resulting ethical questions? How can we avoid compromising our own sense of ethics when we know of unethical practices that may compromise the autonomy of individual JW patients? In part 1 , I will review the perspectives 
provided by dissidents, and discuss the potential impact on medical professionals.

\section{History and doctrinal system}

It is beyond the scope of this paper to present a detailed account of the history and doctrine of JWs. An excellent monograph is available. ${ }^{5}$ The religion informally began in Pennsylvania in the 1870s under the leadership of Charles Taze Russell. He borrowed many of his ideas from Second Adventists and other apocalyptic sects that speculated on "the end of the world" in Bible prophecy. In 1884 Russell founded the WTS, which became the legal corporation used by the International Bible Students, who changed their name to "Jehovah's Witnesses" in 1931. Russell taught that Jesus had invisibly returned from heaven to rule over the earth in 1874 by setting up God's kingdom, and that in 1914 Jesus would come to judge the earth and destroy this world's political, social, economic and religious institutions. When nothing supernatural happened in 1914 and Russell died disappointed in 1916, the religion almost fell apart. However, the second president, Joseph Franklin Rutherford, re-grouped the religion with his charisma and re-shaped the doctrinal system many times, including the prediction of the arrival of Armageddon in 1918, 1920 and 1925, and moving the invisible return of Jesus from 1874 to 1914. Jehovah's Witnesses consider themselves the only true Christians, with all other Christian denominations being so-called "apostate Christendom".

The doctrines crucial to understanding the JW mindset, as it relates to their adherence to the blood policy can be summarized as: 1) Armageddon is near, in which all mankind will be destroyed except faithful JWs who will live forever on earth; 2) The WTS governing body is believed to be the "faithful and discreet slave" referred to in Jesus' parable at Matthew 24:45, divinely appointed by Jesus Christ to lead the JWs; 3) The Bible cannot be understood without interpretation by the "faithful and discreet slave"; 4) JWs who openly criticize the leadership and the organization are regarded as apostates, disloyal to Jesus and God; 5) Salvation is contingent on how well they perform as loyal JWs.

\section{Criticism and dissent}

Recent criticism by dissidents and internal reformers reveals several important JW practices that are critical to re-evaluating our moral support of their blood policy. Here I will review four practices that are repeatedly criticized: intimidation and punishment to enforce strict conformity to
WTS policy; stifled freedom of speech, thought and decision; breach of confidentiality by ins informers, and inconsistencies and contradictions that are undisclosed to the JW rank and file. This material is based on WTS's own publications the testimony of current and former JWs.

ENFORCEMENT OF CONFORMITY

Jehovah's Witnesses are directed to shun friends or relatives who formally leave (disassofiriate) or who are forced to leave (are disfellowshiped from) the organization. Former JWs who voice disagreement with the leaders are labelteod "apostate" and treated the same way as those wo are excommunicated for "sexually immoral" cक्षेduct or other grave sins. The JWs' offidial magazine The Watchtower wrote about the shưnning of "apostates" as follows.

N

"... if a relative, such as a parent, son or daughter, is disfellowshiped or has disassociated himself, blood and family ties remain. Does that meatn, then, that in the family circle everything rema the same when one member is disfellowshipe्d? Definitely not. A disfellowshiped person has be $\vec{\theta}$ n spiritually cut off from the congregations former spiritual ties have been completelyoseyered. This is true even with respect to his relagios, including those within his immediate fan circle. Thus, family members - while acknowledging family ties-will no longer have any spiritgal fellowship with him...." 11

“True Christians share Jehovah's feelings towarids such apostates; they are not curious about apostate ideas. On the contrary, they "feel a loathing" towards those who have made themsel ies God's enemies, but they leave it to Jehovah: execute vengeance....". ${ }^{12}$

Included amongst so-called "apostates" å̊re substantial numbers of conscientious dissenterrs and those who unrepentantly received bloed products. Current JWs are strictly charged sever personal ties with them. Violators are the selves subject to disfellowshiping. Outsiders nuy not realize the trauma of leaving the organization, but for JWs it means total isolation from friends and family members who remain in the organization. Unless they repentantly seek reinstatemerot, there will be no chance of resurrection, and eternal annihilation is their only future. The psyctiological trauma is devastating. There is no honowrable way for JWs to leave their organization.

LACK OF FREEDOM OF SPEECH AND THOUGHT A most serious problem is that free speech, 00r more precisely, free thought and decision-making, are prohibited for JWs. These are crucial to 
self-determination of medical care, yet are seldom mentioned in medical literature. Former governing body member Raymond Franz states: "Watchtower training causes Jehovah's Witnesses to view 'independent thinking' as sinful, an indication of disloyalty to God and his appointed 'channel.' "13 The Watchtower warns JWs against "independent thinking" in harsh language:

"Avoid independent thinking. From the very outset of his rebellion Satan called into question God's way of doing things. He promoted independent thinking. 'You can decide for yourself what is good and bad,' Satan told Eve. 'You don't have to listen to God. $\mathrm{He}$ is not really telling you the truth.'... How is such independent thinking manifested? A common way is by questioning the counsel that is provided by God's visible organization.... Yet certain ones have professed to know better. They have rebelled against such counsel and have done what is right in their own eyes. With what result? Very often they have become involved in sexual immorality and have suffered severe spiritual harm." 14

"Apostates often appeal to the ego, claiming that we have been deprived of our freedoms, including the freedom to interpret the Bible for ourselves.... In reality, these would-be defilers offer nothing more than a return to the nauseating teachings of "Babylon the Great." [Which means all the other religions - note added by this author.] True, such smooth talkers may look outwardly clean in a physical and moral way. But inside they are spiritually unclean, having given in to prideful, independent thinking." 15

Such loaded language discourages discussing or even thinking about critical issues. In combination with the threat of excommunication - which means destruction at Armageddon and eternal annihilation, and the immediate loss of family and friends - it effectively coerces JWs to conform blindly to WTS policy.

\section{FEAR OF BREACH OF CONFIDENTIALITY}

Jehovah's Witnesses face coercion by a potential threat produced by informers among fellow JWs. They are taught to report to congregation elders significant infractions of organizational rules by their fellows. The following article from The Watchtower illustrates the attitude. The article, titled "A time to speak - When", discusses whether a hypothetical Mary, who works at a hospital, should report confidential medical information on fellow JWs to congregation elders:

"Mary works as a medical assistant at a hospital. One requirement she has to abide by in her work is confidentiality. She must keep documents and information pertaining to her work from going to unauthorized persons. Law codes in her state also regulate the disclosure of confidential information on patients. One day Mary faced a dilemma. In processing medical records, she came upon information indicating that a patient, a fellow Christian, had submitted to an abortion. Did she have a Scriptural responsibility to expose this information to elders in the congregation, even though it might lead to her losing her job, to her being sued, or to her employer's having legal problems?"16

After discussing "Bible principles" that apply to this hypothetical situation, the article tells how Mary acted:

"Mary was somewhat apprehensive about the legal aspects but felt that in this situation Bible principles should carry more weight than the requirement that she protect the privacy of the medical records... . So when Mary analyzed all the facts available to her, she decided conscientiously that this was a time to 'speak', not to 'keep quiet'."

The article argues that "there may be times when a Christian is obligated to bring a matter to the attention of the elders", because the law of God outweighs the demands of "lesser authorities". The article concludes:

"There may be occasions when a faithful servant of God is motivated by his personal convictions, based on his knowledge of God's Word, to strain or even breach the requirements of confidentiality because of the superior demands of divine law."

Obviously this teaching applies to JWs who have incidental access to confidential medical information about blood transfusions that may have been secretly given to fellow JWs. While the article gives a hypothetical example, the following footnote shows that JWs apply its counsel in reallife situations:

"Mary is a hypothetical person facing a situation that some Christians have faced. The way she handles the situation represents how some have applied Bible principles in similar circumstances."

This article and other testimonies indicate that there is coercion due to fear of breach of confidentiality by inside informers. Where JWs are employed as medical workers, JW patients have no assurance of doctor-patient confidentiality since, according to WTS teaching, "the law of God" implies that the end justifies the means. 


\section{History of the blood doctrine}

Physicians know little of the history of the blood policy and its enforcement, which raises questions in light of medical ethics. I believe the lack of this knowledge in the medical community contributes to the generally supportive attitude, even though many physicians do not agree with the practice.

\section{CHANGING MEDICAL DOCTRINES}

The WTS has a long history of changing doctrines regarding medical issues. This includes a campaign against aluminium cookware and attacks on the American Medical Association and medical professionals as can be noted from the following:

"We do well to bear in mind that among the drugs, serums, vaccines, surgical operations, etc, of the medical profession, there is nothing of value save an occasional surgical procedure. Their so-called 'science' grew out of Egyptian black magic and has not lost its demonological character... we shall be in a sad plight when we place the welfare of the race in their hands." 17

Few remember that the WTS once denounced vaccinations and organ transplants in severe terms and with flaming rhetoric. They based their prohibitions on the same scriptural interpretations as the current blood prohibition; those practices were "against Jehovah's everlasting covenant with mankind (Genesis 9:4)". They called vaccination "a crime, an outrage, and a delusion" and "the most barbarous practice", ${ }^{18}$ and prohibited organ transplants as "cannibalism", ${ }^{19}$ only quietly to reverse these positions as those practices became standard medical care. Most JWs accepted this reversal without questioning whatever tragedies were caused by the misguided doctrines. Once denounced as strongly as blood transfusions, vaccinations and organ transplants are now considered "matters of conscience" by the WTS. Most JWs receive these treatments routinely, and recent WTS publications describe positively the benefits of vaccination $^{20}$ and successful heart transplants. ${ }^{21}$

While most people dislike constantly changing religious doctrines, JWs are taught to welcome such changes, based on Proverbs 4:18: "the path of the righteous is like the first gleam of dawn, shining ever brighter till the full light of the day." ${ }^{22}$ They are taught that changing doctrines should be welcomed as "new light" or "new understanding" from God and are proof that they are on "the path of the righteous".

\section{BIBLICAL BASIS OF BLOOD DOCTRINE}

Prohibition of blood transfusions was first promulgated in The Watchtower of July 1, 1945. There has been no clear explanation why this medical treatment was suddenly prohibited at that tinfe, even though it had been used since World Wan. One cultural anthropologist has suggested thathit was promulgated to re-establish the sect's internal cohesiveness. ${ }^{23}$ The doctrine is based on thee Biblical passages, which we will discuss from J and dissidents' viewpoints. Note that since Bighe writers knew nothing of blood transfusions, the WTS must equate transfusions with eating blood in order to argue that transfusions are unscreptural. This is discussed at length below.

The first passage is Genesis 9:4, where God (Jehovah) established a covenant with Noah: "Bgyt you must not eat meat that has its lifeblood stillin it". The WTS says that the prohibition agaiogst eating blood is a part of the "eternal covenant wh mankind". However, this is inconsistent with some of their other interpretations. The W does not prohibit birth control which is a clegr breach of the first part of this covenant: "Be fruitfull and increase in number and fill the earth."(Genesis $9: 1)$. The inconsistency is that they obey one partof the covenant but ignore the other part. Parentherically, the majority of Christian Bible scholats believe that the Noachian covenant was no longer binding on mankind after the New Covenafif Jesus Christ was established.

The second passage is from Leviticus 17:1 where God gave a law to Moses, saying: "None.्. you may eat blood, nor may an alien living amo⿳⺈ you eat blood."(Leviticus 17:12) This indeed indicates that God prohibited the Jews from eatipg blood. However, the WTS teaches that Christians are not under the Mosaic Law, which includes dietary laws such as the prohibition on eating pigs and eels. They inconsistently argue that only of dietary law is binding. This can be seen from Leviticus 3:17: "This is a lasting ordinance for the generations to come, wherever you live: You mơ⿱s not eat any fat or any blood." Clearly, the Law prohibited eating fat and blood in the same ternos; yet the WTS only prohibits the eating of blogted, and hence blood transfusions.

The third passage is from Acts 15 where Janfss proposed to write a letter to Gentile Christians, urging them to follow Jewish customs as follow:

"It seemed good to the Holy Spirit and to us to burden you with anything beyond the following requirements: You are to abstain from food sacoiificed to idols, from blood, from the meat of strangled animals and from sexual immorality. You wh1 do well to avoid these things. Farewell."(A \& 15:28,29).

One problem with the WTS application of thes verse to blood transfusions is the lack of evidence that this verse was meant as an everlasting 
command for all Christians in an absolute sense. Most scholars view the context of Acts 15 this way: the so-called Jerusalem Council was held because a dispute arose about whether the Gentile Christians should be circumcised in accordance with the Mosaic Law. The council decided that Christians were not under the Mosaic Law, but in order to maintain a peaceful relationship between Jewish and Gentile Christians the council decided to ask Gentiles to follow the touchiest Jewish traditions, including avoiding eating blood. This interpretation is supported by Paul, who taught that eating food sacrificed to idols is a matter of conscience even though Acts 15 mentions it in the same terms as eating blood.(1 Corinthians 8:4-8)

Ironically, the founder of the WTS, Charles Taze Russell, interpreted Acts 15 in line with many Bible scholars, and considered abstaining from eating blood as "a basis of common fellowship between" Jews and Gentiles and "necessary to the peace of the church", not as an everlasting law for all Christians. ${ }^{24}$ If Russell's interpretation were adopted by the WTS today, the blood prohibition would not exist. Most JWs do not know this.

BLOOD TRANSFUSION THE SAME AS EATING BLOOD The WTS argues that since the Bible forbids eating blood, JWs should not take it into the body by any route including transfusion. Since this conclusion is not stated in the Bible, they resort to circuitous argumentation to equate blood-based medical treatment with eating blood. In support of this, they quote 17th century anatomist Thomas Bartholin ${ }^{25}$ and French physician Jean Baptiste Denys ${ }^{26}$ to show that blood transfusion was equated with nourishing the body by mouth. The WTS fails to mention that modern medicine had abandoned this concept many decades ago. Current blood transfusions merely replace functions lost due to blood loss, such as oxygen transport - a concept entirely different from that held by certain 17 th-century physicians.

The WTS has used the following analogy:

"A patient in the hospital may be fed through the mouth, through the nose, or through the veins. When sugar solutions are given intravenously, it is called intravenous feeding. So the hospital's own terminology recognizes as feeding the process of putting nutrition into one's system via the veins. Hence the attendant administering the transfusion is feeding the patient blood through the veins, and the patient receiving it is eating it through his veins." 27

A more recent version of the scenario is:
"In a hospital, when a patient cannot eat through his mouth, he is fed intravenously. Now, would a person who never put blood into his mouth but who accepted blood by transfusion really be obeying the command to 'keep abstaining from ... blood'?(Acts 15:29) To use a comparison, consider a man who is told by the doctor that he must abstain from alcohol. Would he be obedient if he quit drinking alcohol but had it put directly into his veins?" 28

As any medical professional knows, this argument is false. Orally ingested alcohol is absorbed as alcohol and circulates as such in the blood, whereas orally eaten blood is digested and does not enter the circulation as blood. Blood introduced directly into the veins circulates and functions as blood, not as nutrition. Hence blood transfusion is a form of cellular organ transplantation. And as mentioned before, organ transplants are now permitted by the WTS. These inconsistencies are apparent to physicians and other rational people, but not to JWs because of the strict policy against viewing critical arguments. They continue to view the WTS's illogical analogy as "the Truth".

ARBITRARY RULES ON PROHIBITED VERSUS PERMITTED BLOOD-BASED TREATMENTS

The WTS's initial prohibition of the use of blood covered whole blood transfusions, but over the years many rules and exceptions were developed. For example, the WTS once published an article instructing JWs not to treat their pets with blood transfusions and not to use fertilizer containing blood. ${ }^{29}$ Medical use of leeches also was prohibited. ${ }^{30}$ Those practices were also defined as "against God's Word".

More recently, since medical treatments mostly involve blood components instead of whole blood, the WTS has created a list of prohibited and permitted components. The most notable publication among JWs and the medical community regarding their rules of blood treatments appeared in 1981 in The fournal of the American Medical Association. ${ }^{31}$ The article summarized the basic guidelines for treating JWs using blood products. It was written by a JW physician, $\mathrm{Dr}$ Lowell Dixon, who was head of the medical department at Watchtower headquarters in Brooklyn, New York. This concise article clearly communicated to the medical community the JW position on treatments using blood components. The article has since been referenced in much medical literature as a guideline for treatment of JWs. 
The current JW position includes unconditional refusal of whole blood, packed red blood cells, white blood cells, platelets and plasma. However, they may accept albumin, immunoglobulin, and haemophiliac preparations. Those components are considered a "conscience matter". Perhaps the most peculiar and inconsistent aspect of the JW policy is that they may accept all of the individual components of blood plasma, as long as they are not taken at the same time. In addition, JWs do not even accept autologous transfusion of their own predeposited blood, though intraoperative salvage (or cell saver) is accepted as long as extracorporeal circulation is uninterrupted via a tube. They may also accept treatment by heart-lung and haemodialysis machines. More recently induced haemodilution has been permitted.

The WTS offers no biblical explanation for differentiating between prohibited treatments and treatments which are considered a "matter of conscience". The distinction is entirely based on decisions arbitrarily made by the governing body. When a new blood-based treatment becomes available, the governing body ultimately determines its acceptability before use. ${ }^{32}{ }^{33}$ Jehovah's Witnesses are required to adhere strictly to these rules on the premise of them being Bible-based "Truth".

The governing body teaches that the "prohibited" blood components are "major", whereas acceptable components are "minor" or "small fractions", stating that the major components are limited to only those that pass through the placental barrier during pregnancy, and that on this basis a JW may accept them in good conscience. ${ }^{34}$ This might seem reasonable were it not for the fact that medical science has shown that most "major components" can also pass through the placental barrier. ${ }^{35}$

One subtle irony that most JWs are not aware of is that albumin (one of the permitted components) constitutes $2.2 \%$ of blood volume, whereas white blood cells, and platelets (forbidden components) constitute $1 \%$, and $0.17 \%$ respectively. Jehovah's Witnesses patients and their doctor must somehow rationalize why certain "small fractions" can be permitted when the WTS teaches adamantly that "abstaining from blood means not taking it into our bodies at all" ${ }^{36}$ The WTS also fails to explain why it is permissible for vast quantities of blood to be donated, stored, and processed to produce the "small fractions" JWs are permitted to accept. Yet it teaches JWs that blood must not be used in any purposeful way, prohibiting blood donation with the same punishment as receiving blood. ${ }^{37}$
EXAGGERATED NEGATIVE CAMPAIGN AGAINST BLOOळ TRANSFUSIONS Many WTS publications emphasize the danger blood transfusions and the advantages of alternatives to blood transfusions. Their magazines co tain tragic stories and negative quotes from medi cal journals and news media about the danger blood. Needless to say, there are significant ris in blood transfusions, and patients should informed about them. However, the WToS presents a distorted picture because it fails to report any benefits of blood-based treatments Just as with its campaign against organ transplants and vaccinations, it uses exaggeration and emotionalism to create paranoia against blood transf sions in JWs' minds, while it fails to present objective analysis of risk versus benefit. It ignoris increased risks and cost of some alternatives, nit does it acknowledge that there are no alternatives in some situations. The following paragraph from their official magazine illustrates the persecution mentality the WTS perpetuates, wherein bloof transfusions become "orchestrated by Satan".

"The faith of Jehovah's Witnesses is under attack from all sides - by the clergy of Christendom wh hate the Kingdom message we take from house house, by apostates who collaborate with CHris tendom's clergy, by medical authorities who to impose blood transfusions on us and ofyr children... . All this opposition is orchestrated Satan, the ruler of darkness and ignorance, the enemy of accurate knowledge." 38

As a result of such rhetoric, many JWs are led believe that receiving blood transfusions is as dangerous as playing Russian roulette. ${ }^{39}$ They cann产t see that if blood transfusions did not have proven effectiveness in saving lives, blood would not haze been used to the extent it has by physicians whoge main concern is to save lives and heal disease.

\section{Discussion}

In this critical review, I have presented the histo and religious practices behind JWs' refusal of blood products. Most of the information wias researched by reformers and dissidents and Q found in the WTS's own publications, yet none $\mathscr{O f}_{\mathrm{f}}$ these perspectives are presented objectively to the JW rank and file. Such viewpoints are considered "apostasy" and therefore JWs are warned against them. The coercion in the JW community not $\$$ review and examine critical information is both covert and overt.

How can a physician's attitude towards patients take the above viewpoints into accoun? First, he or she can note that coercive practices and misinformation raise a question regarding the 
autonomy of JW patients. For patients to be truly autonomous, they must be free from undue organizational intimidation and fear of reprisal, and must be given sufficient information, including alternative views. The information presented here suggests a fundamental flaw in most physicians' assumption that JWs are acting autonomously in refusing blood.

Physicians could also scrutinize JW patients more as individuals and recognize that individual JW patients may hold a wider variation in viewpoint than heretofore realized. The current practice of categorical treatment of JW patients should be reassessed, and the possibility of "unorthodox" belief should be explored.

One may argue that JWs joined the religion of their own free will, and that once inside the organization, following the rules established by the leaders, regardless of the inner conflict, is their free choice. It may be further argued that religious freedom includes the freedom to believe in irrational ideas and join coercive groups. Giving consideration to dissident views may be seen as intervening in the internal affairs of the religion.

This argument, however, should be tempered by knowledge of the psychological manipulation, including information control and coercive practices, of certain religious organizations. Many former and current JWs agree that the JW organization has many such elements. I suggest that the autonomy of the members of such groups be scrutinized in light of their unethical practices.

Some may question the reliability of information from dissidents and reformers, particularly those on the Internet, where ethics is yet at a somewhat primitive stage. Although caution must be exercised in relying on the Internet for collecting controversial information, I argue that it provides an unprecedented forum where not only dissidents, but also JWs themselves may voice concerns on issues without reprisal from the WTS, due to the anonymity the Internet affords. Since there is essentially no other avenue available for JWs to "go public" anonymously, bioethicists should consider using the Internet to explore "unofficial" but important information regarding the patients who belong to such religious groups.

In the companion paper, part $2,{ }^{40}$ I will suggest, based on the viewpoints presented here, a rational approach to JW patients who refuse blood products.

\section{Disclaimer}

Views and opinions expressed herein are personal and do not reflect those of Kaiser Permanente and Pacific Permanente PC.
Osamu Muramoto, MD, PhD, is a member of the ethics committee at Kaiser Permanente Northwest Division, and a neurologist at Northwest Permanente PC, Portland, Oregon, USA. Address correspondence to him at: Kaiser East Interstate Medical Office, 3414 N Kaiser Center Drive, Portland, Oregon 97227, USA.e-mail:muramotosa@kpnw.org

\section{Editor's note}

A reply to this paper, by David Malyon, chairman of the JW Hospital Liaison Committee, Luton, will appear in the October issue of the journal.

\section{References and notes}

1 Robb N. Jehovah's Witnesses leading education drive as hospitals adjust to no blood requests. Canadian Medical Association fournal 1996;154:557-60.

2 Spence RK. Surgical red blood cell transfusion practice policies. The American fournal of Surgery 1995;170(6a):3S$15 \mathrm{~S}$.

3 Franz R. Crisis of conscience. Atlanta: Commentary Press, 1992.

4 Franz R. In search of Christian freedom. Atlanta: Commentary Press, 1991.

5 Penton MJ. Apocalypse delayed. The story of fehovah's Witnesses. Toronto: University of Toronto Press, 1985.

6 Botting H, Botting G. The Orwellian world of fehovah's Witnesses. Toronto: University of Toronto Press, 1984.

7 Reed DA. Blood on the altar. Confessions of a fehovah's Witness minister. Amherst: Prometheus Books, 1996. See also book review: Mann M. Jehovah's Witnesses. Fournal of American Medical Association 1997; 277: 425.

8 Beacon light for former Jehovah's Witnesses: http:// www.xjw.com/

9 New light on blood. Official site of the associated Jehovah's Witnesses for reform on blood: http://www.visiworld.com/ starter/newlight/index.htm

10 All along the watchtower: http://home.sol.no/ jansh/wteng/ jwindex.html

11 Anonymous. If a relative is disfellowshiped ... The Watchtower 1981 Sept 15:28.

12 Anonymous. Search through me, O God. The Watchtower 1993 Oct $1: 19$.

13 See reference 4:409.

14 Anonymous. Exposing the devil's subtle designs The Watchtower. 1983 Jan 15: 2.

15 Anonymous. Are you remaining clean in every respect? The Watchtower 1987 Nov 1:19

16 Anonymous. A time to speak - when? The Watchtower 1987 Sept $1: 12$.

17 Shelton HM. Eugenics and barbarism. The Golden Age. 1931 Aug 5: 727-8.

18 Richards HR. Vaccination. The Golden Age 1929 May 1: 502.

19 Anonymous. Questions from readers. The Watchtower 1967 Nov 15:702.

20 Anonymous. Efforts to save the children. Awake! 1994 May 8:4.

21 Anonymous. Bloodless heart transplant. Awake! 1994 May 22:7.

22 Proverbs 4:18. The Bible. All the Bible quotes in this article are from the New International Version.

23 Singelenberg $R$. The blood transfusion taboo of Jehovah's Witnesses: origin, development and function of a controversial doctrine. Social Science and Medicine 1990; 31:515-23.

24 Russell CT. Settling doctrinal differences. The Watchtower 1909 Apr 15:117.

25 Anonymous. How can blood save your life? Brooklyn: Watch Tower Bible and Tract Society of Pennsylvania, 1990:6.

26 Anonymous. Respect for the sanctity of blood. The Watchtower 1961 Sept 15:558.

27 Anonymous. Questions from readers. The Watchtower $1951 \mathrm{Jul}$ 1: 415 .

28 Anonymous. Reasoning from the scriptures. Brooklyn: Watch Tower Bible and Tract Society of Pennsylvania, 1989:73.

29 Anonymous. Questions from readers. The Watchtower $1964 \mathrm{Feb}$ 15:127. 
30 Anonymous. Questions from readers. The Watchtower 1982 Jun $15: 31$.

31 Dixon JL, Smalley MG. Jehovah's Witnesses. The surgical/ ethical challenge. Fournal of the American Medical Association 1981;246:2471-2.

32 Kerridge I, Lowe M, Seldon M, Enno A, Deveridge S. Clinical and ethical issues in the treatment of a Jehovah's Witness with acute myeloblastic leukemia. Archives of Internal Medicine 1998;157:1753-7.

33 Muramoto O. Medical ethics in the treatment of Jehovah's Witnesses. Archives of Internal Medicine 1998;158:1 155-6.

34 Anonymous. Questions from readers. The Watchtower 1990 Jun $1: 31$.
35 Simpson JL, Elias S. Isolating fetal cells in maternal circulation for prenatal diagnosis. Prenatal Diagnosis 1994;14:1229-42.

36 Anonymous. Godly respect for life and blood. The Watchtorter 1969 Jun 1:327.

37 Anonymous. Questions from readers. The Watchtower 1961 fon 15:64.

38 Anonymous. Why we need accurate knowledge. The Watchto $\overrightarrow{\overline{3}}$ 1989 Dec 1:12

39 Anonymous. Gift of life or kiss of death? Awake! 1990 Oct 229.

40 Muramoto O. Bioethics of the refusal of blood by Jehovats Witnesses: part 2. A novel approach based on ration non-interventional paternalism. Fournal of Medical Ethics $19 \%$ 24: (in press).

\section{News and notes}

\section{Annual Intensive Course on Medical Ethics}

The Annual Intensive Course on Medical Ethics will be held from the 14th to the 18th of September 1998 at Imperial College, London. The course provides a multidisciplinary introduction to philosophical medical ethics for medical and nursing teachers, members of ethics committees, GPs, hospital consultants and health administrators. It is organised in collaboration with the Institute of Medical Ethics. Lectures/seminars and small and large groups are led by leading international authorities in the field of medical ethics. PGEA and CME accreditation sought.

For further information contact: Sally Verkaik, Imperial College Continuing Education Centre, London SW7 2AZ. Telephone: +44 (0)171 594 6882; fax: +48 (0)171 594 6883; E-mail: cpd@ic.ac.uk 
duty of professionals to treat their patients, clients, and customers with reasonable skill and prudence.

In conclusion, if on the basis of its merits, one is inclined to endorse a "wrongful life" compensation action initiated by a handicapped newborn against a negligent genetic counsellor, one need not be deterred by such speculative and highly irrelevant "slippery slope" apprehensions.

Amost Shapira MFur, MCL, FSD, is Professor of Law, former Dean, Faculty of Law, Tel Aviv University, Israel, Incumbent of the Lubowski Chair of Law and Biomedical Ethics, Faculty of Law, Tel Aviv University, and Director, Minerva Center for Human Rights, Tel Aviv University.

\section{References}

1 For an expanded version of this essay see: Shapira $A$. The human right not to be born impaired: issues of logic, value and policy. In: Immenga U et al, eds. Festschrift fur Ernst-foachim Mestmacker. Baden-Baden, Germany: Nomos, 1996: 293; and Shapira A. "Wrongful life" lawsuits for faulty genetic counselling: the impaired newborn as plaintiff. Tel Aviv University Studies in Law 1997;13:97-114.

2 CA 518, 540/82, Zeitzoff v Katz, [1986] 40(2) PD 85 (Supreme Court of Israel).

3 For a discussion supporting the view that the fundamental problems in dealing with the "wrongful life" concept relate to the physician's alleged duty to the fetus and the notion of life as a harm, see Botkin JR. The legal concept of wrongful life. fournal of the American Medical Association 1988;259:1541.

4 For a position favouring parental responsibility to avoid a "wrongful life", see Steinbock B, McClamrock R. When is birth unfair to the child? Hastings Center Report 1994;24:15. For a skeptical view as to parental obligations in this regard, see Dworkin RB.The new genetics. In: Childress JF et al, eds. Bio law (resource manual) 1986;1:89, 100-1.

\section{Correction}

Bioethics of the refusal of blood by fehovah's Witnesses: part 1. Should bioethical deliberation consider dissidents' views? There was a mistake in this paper by Dr Osamu Muramoto, which was published in the August issue of the journal. Dr Muramoto has written to the journal apologising for his mistake and asking that an erratum note be published.

The sentence containing the mistake was published thus: The governing body teaches that the "prohibited" blood components are "major", whereas acceptable components are "minor" or "small fractions", stating that the major components are limited to only those that pass through the placental barrier during pregnancy, and that on this basis a JW may accept them in good conscience.

It should have read (changed word in bold):The governing body teaches that the "prohibited" blood components are "major", whereas acceptable components are "minor" or "small fractions", stating that the minor components are limited to only those that pass through the placental barrier during pregnancy, and that on this basis a JW may accept them in good conscience. 